\title{
Pengaruh Kecerdasan Intelektual Dan Kecerdasan Emosional Terhadap Kinerja Karyawan Pada PT. Bank Rakyat Indonesia (Persero) Cabang Tangerang Merdeka
}

\author{
Prasetyo Kurniawan \\ Dosen Fakultas Ekonomi Universitas Pamulang \\ Email : $\underline{\text { dosen02661@unpam.ac.id }}$
}

\begin{abstract}
ABSTRAK
Penelitian ini bermaksud untuk mengetahui dan menganalisis pengaruh kecerdasan intelektual dan kecerdasan emosional terhadap kinerja karyawan Pada PT. Bank Rakyat Indonesia (PERSERO) Cabang Tangerang Merdeka baik secara parsial maupun secara simultan.

Metode yang penulis gunakan dengan menggunakan metode Asosiatif, teknik sampling yang penulis gunakan dengan sampling jenuh. Jumlah sampel yang penulis teliti sebanyak 95 karyawan, pengumpulan data dalam penelitian ini menggunakan kuesioner sedangkan metode analisis data menggunakan regresi linier berganda.

Penelitian ini memberikan bukti empiris bahwa kecerdasan intelektual berpengaruh positif dan signifikan terhadap kinerja karyawan hal tersebut dapat dibuktikan dari nilai regresi 0,153 (positif) dan nilai signifikasi kecerdasan intelektual sebesar 0,003. Semakin tinggi dan baik kecerdasan intelektual karyawan dalam bekerja maka akan semakin tinggi kinerja karyawan tersebut. Kecerdasan Emosional berpengaruh positif dan signifikan terhadap kinerja karyawan hal tersebut dapat dibuktikan dari nilai regresi 0,355 (positif) dan nilai signifikasi kecerdasan emosional sebesar 0,000. Semakin tinggi dan baik karyawan dalam mengendalikan kecerdasan emosionalnya dalam bekerja maka akan semakin tinggi pula kinerja karyawan tersebut. Kecerdasan Intelektual dan kecerdasan emosional berpengaruh positif dan signifikan terhadap kinerja karyawan hal tersebut dapat dibuktikan hasil uji $\mathrm{F}$ diperoleh nilai signifikasi sebesar 0,000 serta pengaruh secara simultan antara kedua variabel bebas yaitu kecerdasan intelektual dan kecerdasan emosional terhadap kinerja karyawan sebesar 67,3\%. Semakin tinggi dan baik kecerdasan intelektual dan kecerdasan emosional karyawan dalam bekerja maka akan semakin tinggi kinerja karyawan tersebut.
\end{abstract}

\section{Kata Kunci : Kecerdasan Intelektual, Kecerdasan Emosional Dan Kinerja Karyawan.}




\section{PENDAHULUAN}

Tidak dapat dipungkiri lagi bahwa tidak hanya kecerdasan intelektual (IQ) saja yang dapat menentukan peningkatan dan kecerdasan manusia, tetapi bahwa peningkatan dan kecerdasan atau kinerja manusia juga dapat dipengaruhi oleh kecerdasan emosional (EQ). Untuk alasan ini, Kecerdasan Intelektual (IQ) dan Emotional Intelligence (EQ) yang dimiliki karyawan perlu diteliti dan dikembangkan untuk memiliki dampak positif dan signifikan terhadap kinerja karyawan untuk memfasilitasi kinerja karyawan.

Tentu saja, di tempat kerja, karyawan harus memiliki kecerdasan (IQ) yang memadai untuk menggunakan keterampilan kognitif mereka dengan baik di tempat kerja. Menurut Robins dan Judge (2007:52), "IQ adalah kemampuan yang dibutuhkan untuk melakukan berbagai aktivitas mental semakin tinggi IQ seseorang, semakin tinggi juga kemampuannya untuk menghadapi masalah yang berhubungan dengan kemampuan spasial, numerikal, dan linguistik". Pada dasarnya, IQ berpikir sesuai dengan aturan logika formal, melalui tahap demi tahap dan terikat aturan.

Faktor selanjutnya dalam mempengaruhi kinerja karyawan adalah kecerdasan emosional. Menurut Goleman (2015) "Kecerdasan emosional (EQ) merupakan kemampuan individu untuk mengenal emosi diri sendiri, emosi orang lain, memotivasi diri sendiri, dan mengelola dengan baik emosi pada diri sendiri dalam berhubungan dengan orang lain". EQ adalah istilah baru yang dipopulerkan oleh Daniel Golleman. Berdasarkan hasil penelitian para neurolog dan psikolog, Goleman (2015) berkesimpulan bahwa "setiap manusia memiliki dua potensi pikiran, yaitu pikiran rasional dan pikiran emosional. Pikiran rasional digerakkan oleh kemampuan intelektual atau "Intelligence Quotient", sedangkan pikiran emosional digerakkan oleh emosi".

Penelitian ini dilakukan pada PT. Bank Rakyat Indonesia (PERSERO) Cabang Tangerang Merdeka berdasarkan hasil observasi yang penulis lakukan pada perusahaan ini diperoleh permasalahan terkait rendahnya kecerdasan intelektual dan emosional karyawan seperti kurangnya kemampuan karyawan untuk menyesuaikan diri terhadap tugastugas baru yang diberikan oleh perusahaan sehingga mengakibatkan terhambatnya proses pelayanan yang cepat. Masih ada beberapa karyawan yang masih belum faham terhadap produk yang ditawarkan kepada calon nasabah. Masih adanya keluhan pelanggan terkait sikap petugas dalam melayani pelanggan dengan tidak sopan atau kurang ramah serta kurang tanggap dalam menanggapi dan menyelesaikan keluhan konsumen sesuai permasalahan yang dihadapi ketika melakukan transaksi.

Yenti (2013) meneliti "pengaruh Kecerdasan Emosional, Kecerdasan Intelektual dan Kecerdasan Spiritual terhadap Kinerja Karywan pada R.S Pekan Baru mengatakan ada pengaruh secara signifikan terhadap kinerja karyawan". Selanjutnya Goleman (2015) "manyimpulkan pula bahwa pencapaian kinerja ditentukan hanya 
$20 \%$ dan IQ, sedangkan $80 \%$ lagi ditentukan oleh kecerdasan emosi”. Senada dengan pendapat Joan Beck menyatakan bahwa "IQ sudah berkembang $50 \%$ sebelum usia 5 tahun. $80 \%$ berkembangnya sebelum usia 8 tahun, dan hanya berkembang $20 \%$ sampai akhir masa remaja, sedangkan kecerdasan emosi dapat dikembangkan tanpa batas waktu".

METODE PENELITIAN

Metode yang digunakan dalam penelitian ini adalah metode asosiatif, metode pengambilan sampel yang digunakan adalah sampling jenuh dan sampel yang digunakan adalah 95 karyawan, sedangkan metode analisis data dimulai dengan penyebaran kuesioner, kemudian uji validasi, kemudian uji validasi, kemudian uji asumsi. Kemudian dianalisis menggunakan regresi linier berganda, pengujian hipotesis, dan koefisien determinasi.

\section{HASIL PENELITIAN DAN PEMBAHASAN}

\section{A. Uji Validitas dan Reliabilitas}

Tabel 1 Hasil Uji Validitas

\begin{tabular}{|l|c|c|c|c|c|}
\hline \multicolumn{1}{|c|}{ Pernyataan } & $\mathbf{r}_{\text {hitung }} \mathbf{X}_{\mathbf{l}}$ & $\mathbf{r}_{\text {hitung }} \mathbf{X}_{\mathbf{2}}$ & $\mathbf{r}_{\text {hitung }} \mathbf{Y}$ & $\mathbf{r}_{\text {tabel }}$ & Keputusan \\
\hline Pernyataan 1 & 0,784 & 0,810 & 0,833 & 0,201 & Valid \\
\hline Pernyataan 2 & 0,756 & 0,916 & 0,929 & 0,201 & Valid \\
\hline Pernyataan 3 & 0,799 & 0,875 & 0,921 & 0,201 & Valid \\
\hline Pernyataan 4 & 0,758 & 0,907 & 0,372 & 0,201 & Valid \\
\hline Pernyataan 5 & 0,765 & 0,903 & 0,411 & 0,201 & Valid \\
\hline Pernyataan 6 & 0,885 & 0,891 & 0,921 & 0,201 & Valid \\
\hline Pernyataan 7 & 0,815 & 0,919 & 0,579 & 0,201 & Valid \\
\hline Pernyataan 8 & 0,874 & 0,858 & 0,420 & 0,201 & Valid \\
\hline Pernyataan 9 & 0,867 & 0,888 & 0,870 & 0,201 & Valid \\
\hline Pernyataan 10 & 0,726 & 0,847 & 0,578 & 0,201 & Valid \\
\hline
\end{tabular}

Sumber: Data Diolah Penulis 2019

Dari hasil pengujian data tersebut menunjukan bahwa seluruh 30 butir pernyataan item kuesioner memiliki ketepatan data yang valid dilihat dari angka $r_{\text {hitung }}$ jauh lebih tinggi dari standar kritis 0,201 .

Tabel 2 Hasil Uji Reliabilitas

\begin{tabular}{|c|c|c|c|}
\hline Variabel & Cronbach Alpha & Vilai Kritis & Keputusan \\
\hline Kecerdasan Intelektual & 0.938 & 0,60 & Reliabel \\
\hline Kecerdasan Emosional & 0,968 & 0,60 & Reliabel \\
\hline Kimeria Karravian & 0.883 & 0.60 & Reliabel \\
\hline
\end{tabular}

Sumber: Data Diolah Pendlis 2019

Pada tabel 2 dari ketiga variabel yang diteliti baik variabel bebas (kecerdasan intelektual dan kecerdasan emosional) maupun variabel terikat (kinerja karyawan) memiliki nilai alpha cronbach diatas 0,60 ini berarti semua butir instrumen sebanyak 30 pernyataan kuesioner adalah reliabel.

\section{B. Uji Asumsi Klasik}

1. Normalitas

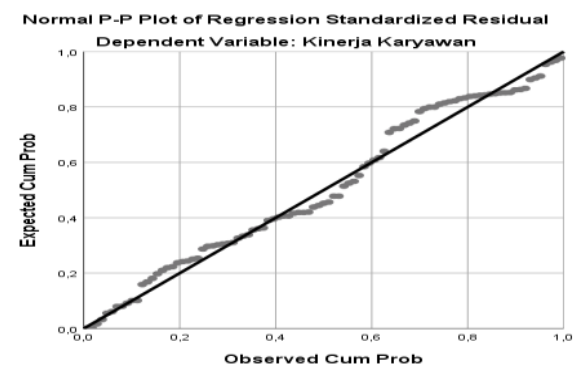

Gambar 1. Hasil Uji Normalitas

Pada gambar 1 tersebut sebaran data mengikuti arah atau garis diagonal yang searah sehingga asumsi normaitas sudah terpenuhi. 


\section{Multikolineritas}

\begin{tabular}{|c|c|c|}
\hline \multirow{2}{*}{ Model } & \multicolumn{2}{|c|}{ Collinearity Statistics } \\
\hline & Tolerance & VIF \\
\hline \multicolumn{3}{|l|}{1 (Constant) } \\
\hline Kecerdasan Intelektual & 0,628 & 1,592 \\
\hline Kecerdasan Emosional & 0,628 & 1,592 \\
\hline
\end{tabular}

Tabel 3 terlihat bahwa angka VIF yang lebih rendah dari 10 dan nilai tolerance yang lebih besar dari angka 0,1 maka dinyatakan terbebas multikolinerias.

\section{Heteroskedastisitas}

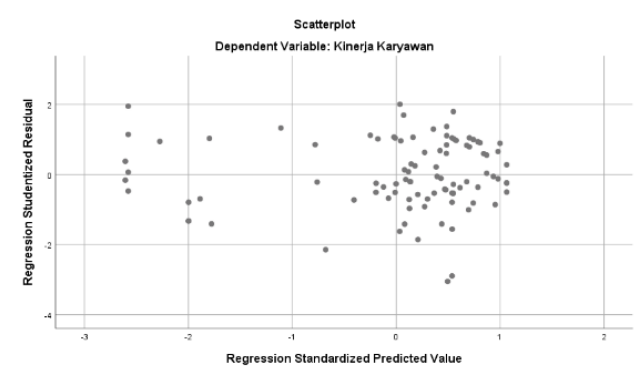

Gambar 2. Uji Heteroskedastisitas

Pada gambar 2 sebaran data yang menyebar baik dari atas maupun dari bawah hal ini tidak terjadi gejala heteroskedastisitas.

\section{Uji Regresi Linier Berganda}

\begin{tabular}{|c|c|c|c|c|c|}
\hline \multirow[t]{2}{*}{ Model } & \multicolumn{2}{|c|}{$\begin{array}{l}\text { Unstandardized } \\
\text { Coefficients }\end{array}$} & \multirow{2}{*}{$\begin{array}{c}\text { Standardized } \\
\text { Coefficients } \\
\text { Beta }\end{array}$} & \multirow[t]{2}{*}{$t$} & \multirow[t]{2}{*}{ Sig. } \\
\hline & & & & & \\
\hline 1 (Constant) & 20,521 & 1,605 & & 12,789 & .000 \\
\hline Kecerdasan Intelektual & .153 & .049 & .234 & 3,108 & .003 \\
\hline Kecerdasan Emosional & 355 & 041 & .657 & 8,734 & .000 \\
\hline \multicolumn{6}{|c|}{$\begin{array}{l}\text { a. Dependent Variable: Kinerja Karyawan } \\
\text { Sumber: Data Diolah Penulis } 2019\end{array}$} \\
\hline \multicolumn{6}{|c|}{$Y=20,521+0,153 X_{1}+0,355 X_{2}$} \\
\hline & \multicolumn{5}{|c|}{$\begin{array}{l}\text { 1. Konstanta sebesar 20,521 } \\
\text { memperlihatkan bahwa jika } \\
\text { variabel kecerdasan intelektual } \\
\text { dan kecerdasan emosional tidak } \\
\text { meningkat maka kinerja } \\
\text { karyawan akan tetap terbentuk } \\
\text { sebesar } 20,521 \text {. }\end{array}$} \\
\hline
\end{tabular}

2. Nilai regresi $X_{1} 0,153$ (positif) yang bermakna apabila kecerdasan intelektual mengalami peningkatan maka kinerja karyawan juga akan naik sebesar 0,153 .

3. Nilai regresi $X_{2} 0,355$ (positif) yang bermakna apabila kecerdasan emosional mengalami peningkatan maka kinerja karyawan juga akan naik sebesar 0,355 .

\section{Uji Hipotesis}

\section{Uji Hipotesis Parsial}

Tabel 4 Uji Hipotesis Parsial

\begin{tabular}{ll|l|l|l}
\hline Model & $\begin{array}{c}\text { Unstandardized } \\
\text { Coefficients }\end{array}$ & $\begin{array}{l}\text { Standardized } \\
\text { Coefficients }\end{array}$ & t & Sig.
\end{tabular}

\begin{tabular}{lrrrrr}
\hline (Constant) & B & Std. Error & Beta & & \\
\hline
\end{tabular}

\begin{tabular}{llllll} 
Kecerdasan Intelektual &, 253 &, 049 &, 234 & 3,108 &, 003 \\
\hline
\end{tabular}

\begin{tabular}{rr|rrrrr}
\hline Kecerdasan Emosional & $; 355$ &, 041 &, 657 & 8,734 &, 000 \\
\hline
\end{tabular}

a. Dependent Variable: Kinerja Karyawan

Sumber: Data Diolah Penulis 2019

Nilai yang tertera pada signifikasi kecerdasan intelektual sebesar 0,003, kemudian nilai yang tertera pada signifikansi kecerdasan emosional sebesar 0,000 jauh lebih rendah dari margin eror $5 \%$. Memberikan bukti empiris bahwa secara parsial kedua variabel bebas tersebut yaitu kecerdasan intelektual dan kecerdasan emosional memiliki pengaruh yang positif dan signifikan terhadap kinerja karyawan.

\section{Uji Hipotesis Simultan}

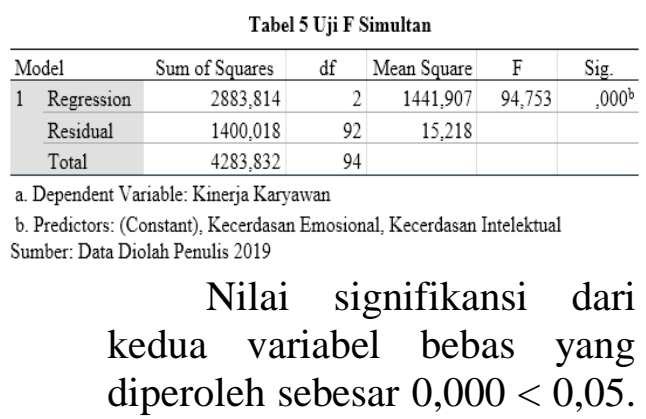


Kecerdasan intelektual dan kecerdasan emosional secara serempak memiliki pengaruh yang positif dan signifikan terhadap kinerja karyawan pada PT. Bank Rakyat Indoensia (Persero) Cabang Tangerang Merdeka.

\section{Uji Koefisien Determinasi}

Tabel 6 Cjij Koefisien Determinasi

\begin{tabular}{lrrrr}
\hline Model & $R$ & RSquare Adjusted RSquare & Std. Eroo of the Estimate \\
\hline 1 &, $820^{2}$ &, 673 &, 660 & 3,0097 \\
\hline
\end{tabular}

a. Predictors: (Constant), Kecerdasann Emosional, Kecerdasan Intelektual Sumber: Data Diolah Penulis 2019

Tabel 6 menunjukan bawa secara simultan kontribusi antara kedua variabel bebas yaitu kecerdasan intelektual dan kecerdasan emosional sebesar $67,3 \%$ terhadap kinerja karyawan. Sementara itu faktor-faktor lain yang mempengaruhi kinerja karyawan selain variabel yang diteliti sebesar $32,7 \%$.

\section{KESIMPULAN DAN SARAN}

\section{A. Kesimpulan}

1. Kecerdasan Intelektual berpengaruh positif dan signifikan terhadap kinerja karyawan hal tersebut dapat dibuktikan dari nilai regresi 0,153 (positif) dan nilai signifikasi kecerdasan intelektual sebesar 0,003. Semakin tinggi dan baik kecerdasan intelektual karyawan dalam bekerja maka akan semakin tinggi kinerja karyawan tersebut.

2. Kecerdasan Emosional berpengaruh positif dan signifikan terhadap kinerja karyawan hal tersebut dapat dibuktikan dari nilai regresi 0,355 (positif) dan nilai signifikasi kecerdasan emosional sebesar 0,000. Semakin tinggi dan baik karyawan dalam mengendalikan kecerdasan emosionalnya dalam bekerja maka akan semakin tinggi pula kinerja karyawan tersebut.

3. Kecerdasan Intelektual dan kecerdasan emosional berpengaruh positif dan signifikan terhadap kinerja karyawan hal tersebut dapat dibuktikan hasil uji $\mathrm{F}$ diperoleh nilai signifikasi sebesar 0,000 serta pengaruh secara simultan antara kedua variabel bebas yaitu kecerdasan intelektual dan kecerdasan emosional terhadap kinerja karyawan sebesar $67,3 \%$. Semakin tinggi dan baik kecerdasan intelektual dan kecerdasan emosional karyawan dalam bekerja maka akan semakin tinggi kinerja karyawan tersebut.

\section{B. Saran}

Diharapkan agar perusahaan perlu memberikan suatu pelatihan khusus berupa pembekalan knowledge dan skill yang disesuaikan dengan kebutuhan dan tugas-tugas yang berdasarkan kewajibannya. Sehingga kemampuannya dalam bekerja, memecahkan masalah, menganalisa, ataupun memutuskan suatu persoalan dapat menjadi lebih baik.

\section{DAFTAR PUSTAKA}

Anwar Prabu Mangkunegara. 2015. Manajemen Sumber Daya Manusia Perusahaan, PT. Remaja Rosdakarya, Bandung. Arikunto, 2013, Prosedur Penelitian Edisi Revisi, Rineka Cipta, Jakarta. 
Ary, Ginanjar Agustian, 2001, Rahasia Sukses Membangun Kecerdasan Emosi \& Spritual ESQ, Jakarta: Agra.

Azwar, Sarifuddin. 2008. Sikap manusia: Teori dan pengukurannya (ed.4). Yogyakarta: Pustaka Pelajar.

Cooper, R.K. \& Sawaf, A. 2002. Executive EQ: Kecerdasan Emosional Dalam Kepemimpinan dan Organisasi. PT Gramedia Pustaka Utama. Jakarta.

Ghozali, Imam, 2016, Aplikasi Analisis Multivariate dengan Program IBM SPSS. Universitas Diponegoro, Yogyakarta.

Goleman, Daniel, 2015. Emotional Intelligence: Kecerdasan emosional mengapa EI lebih penting daripada IQ, Jakarta: PT. Gramedia Pustaka Utama.

Kurniawan Prasetyo, 2019, Pengaruh Disiplin Kerja, Motivasi, Dan Komitmen Organisasi Terhadap Kinerja Karyawan Pada PT. Bank Rakyat Indonesia (Persero) Cabang Tangerang Merdeka, Jurnal Ekonomi Efektif, Vol. 1. No. 2. Nggermanto, Agus, 2002, Quantum Quotient Cara Cepat Melejitkan IQ, EQ, dan SQ. Secara Harmonis, Bandung: Yayasan Nuansa Cendeka.

Purwanto Ngalim, 2013. Evaluasi hasil belajar, Yogyakarta: Pustaka Pelajar.

Rialmi, Z., \& Morsen, M. (2020). Pengaruh Komunikasi Terhadap Kinerja Karyawan PT
Utama Metal Abadi. JENIUS, 3(2), 221-227.

Rialmi, Z. (2017). Pengaruh Keadilan Prosedural Yang Diterapkan Kepemimpinan Pegawai Dan Kepuasan Kerja Pegawai Terhadap Kinerja Dari Pegawai BPBD Provinsi Riau. Jurnal Mandiri: Ilmu Pengetahuan, Seni, dan Teknologi, 1(2), 353374.

Robbins SP, dan Judge. 2007. Perilaku Organisasi, Salemba Empat, Jakarta.

Robert dan Bacal. 2016. Performance Management. Jakarta: Gramedia Pustaka Utama.

Sugiyono, 2017, Metode Penelitian Manajemen, CV Alvabeta, Bandung.

Sunarsi, D. (2016, October). Pengaruh Minat, Motivasi Dan Kecerdasan Kognitif Terhadap Prestasi Belajar (Studi Kasus Pada Mahasiswa Program Studi S-1 Manajemen. Fakultas Ekonomi. Universitas Pamulang. Thn. Akademik 2015-2016). In Proceedings (Vol. 1, No. 1).

Sunarsi, D. (2018). Buku Ajar: Seminar Perencanaan Sumber Daya Manusia. Tangerang Selatan: Asmoro Mediatama

Yenti, Nofry dan Machasin, 2014. Pengaruh Kecerdasan Emosinal, Kecerdasan Intelektual, dan Kecerdasan Spiritual Terhadap Kinerja Karyawan pada RS. Pekan Baru, Jurnal Online Mahasiswa, Vol. 1, No. 2. ISSN. 2355-6854. 